\title{
Signed By
}

National Cancer Institute

\section{Source}

National Cancer Institute. Signed By. NCI Thesaurus. Code C125891.

Indicates the person who has signed a document, physically or electronically (digital signature). 